\title{
Diagnostyka punktowych złączy zgrzewanych metodą szerografii elektronowej
}

\section{Diagnostics of spot weldments using electron shearography}

\section{Streszczenie}

Opracowano metodykę badań nieniszczących wyznaczenia średnicy jądra punktowych połączeń zgrzewanych metodą szerografii elektronowej.

Ustalono, że do oceny rozmiaru jądra punktowych połączeń zgrzewanych konieczne jest otrzymanie podziału pochodnych składowych wektorów przemieszczeń od mechanicznego albo termicznego obciążenia wzdłuż przecięcia, które przechodzi przez centrum punktu. Na krzywej podziału zaznaczonych pochodnych obserwuje się ekstrema odległości odpowiadające średnicy jądra.

Przeprowadzono kompleksowe badania eksperymentalne, które pokazały efektywność mechanicznego obciążenia do użycia na testowych wzorcach w warunkach laboratoryjnych i perspektywy termicznego obciążenia dla bezstykowych badań nieniszczących wyznaczenia średnic jąder punktowych połączeń zgrzewanych cienkościennych konstrukcji w warunkach przemysłowych.

Za pomocą opracowanej metody i sprzętu wyznaczono wielkość jądra punktowego połączenia zgrzewanego, znajdującego się w otoczeniu innych punktów.

\section{Abstract}

Non-destructive method has been developed for determination of weld spot nugget diameter using electron shearography.

It was established that to evaluate the weld spot nugget size it is necessary to obtain the distribution of derivatives from components of displacement vectors as a result of mechanical or thermal loading along the section which passes through the spot center. The extremums are observed in the curve of distribution of marked derivatives, the distance between extremums corresponds to the nugget diameter.

A series of experimental studies was made, which showed the efficiency of mechanical loading for its application on test samples in the laboratory conditions and the challenge of thermal loading for no-contact non-destructive determination of diameters of nuggets of spot welded joints of thin-sheet structures under the industrial conditions.

On the basis of the developed method and equipment the studies were made with determination of value of nugget of weld spot located in the spots clustering.

\section{Wstęp}

W czołowych branżach współczesnego przemysłu, zwłaszcza w przemyśle motoryzacyjnym i okrętownictwie, energetyce, lotnictwie, branży kosmicznej, budowie maszyn, przy wyrobie cienkościennych konstrukcji szeroko wykorzystuje się punktowe połączenia zgrzewane. Najbardziej rozpowszechniony sposób ich otrzymania

Prof. dr hab. inż. Leonid M. Lobanow, dr inż. Wjaczeslaw A. Piwtorak - Instytut Elektrospawalnictwa im. Je. O. Patona Państwowej Akademii Nauk w Kijowie.

to punktowe zgrzewanie różnych materiałów konstrukcyjnych [1].

Zdolność do pracy połączeń zgrzewanych, dokonanych kontaktowym punktowym zgrzewaniem, przeważnie wyznacza się rozmiarem obszaru wzajemnego roztapiania metalu, wolnego od powierzchniowych folii (powłok), czyli rozmiarami jądra punktowego połączenia zgrzewanego. Przy czym trzeba zaznaczyć, że średnica jądra punktowego połączenia zgrzewanego może zmieniać się wskutek odchylenia parametrów procesu zgrzewania albo innych czynników technologicznych. To może doprowadzić do braku zgrzania - defektu, który charakteryzuje się niedostatecznym albo 
nieobecnym jądrem punktowego połączenia zgrzewanego.

W celu otrzymania punktowych połączeń zgrzewanych wysokiej jakości prowadzi się kontrolę parametrów technologicznych podczas kontaktowego zgrzewania i badania nieniszczące gotowego wyrobu z użyciem ultradźwięków, badań rentgenowskich, prądów wirowych, metod magnetycznych $[2 \div 4]$. Jednak wymienione metody kontroli nieniszczącej nie zapewniają pełnego ujawnienia defektów punktowych połączeń zgrzewanych. To doprowadza do konieczności zwiększenia ilości zgrzewanych punktów w celu zagwarantowania wytrzymałości i trwałości konstrukcji zgrzewanej. Ważne dla zabezpieczenia jakościowego połączenia zgrzewanego jest kontrola wymiaru jądra zgrzeiny. Pozostaje aktualne stworzenie operatywnej współczesnej metody kontroli nieniszczącej jakości punktowych połączeń zgrzewanych, co dałoby również możliwość wyznaczania wymiaru średnicy jądra punktowych połączeń zgrzewanych.

Nowe moźliwości daje szerografia elektronowa

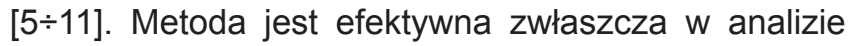
odkształcenia, ponieważ eliminuje się proces liczbowego różnicowania przemieszczeń. Przy użyciu metody szerografii rejestrowane są pochodne przemieszczeń, czyli jest ona nieczuła na przemieszczenia badanego obiektu, nie wywołuje odkształceń, a więc jej stosowanie nie wymaga dodatkowej ochrony od wibracji.

Użycie szerografii elektronowej do nieniszczącej kontroli jakości przewiduje porównanie stanów kontrolowanej powierzchni badanego obiektu przed i po jego obciążeniu.

Celem przeprowadzonej pracy jest badanie możliwości użycia metody szerografii elektronowej do oceny rozmiaru jądra punktowych połączeń zgrzewanych i wyznaczenia efektywnego sposobu ich obciążenia.

\section{Materiały i przebieg badań}

Przy prowadzeniu kontroli jakości konstrukcji metodą szerografii elektronowej największe rozpowszechnienie zyskały następujące główne sposoby ich obciążenia: mechaniczny i cieplny. Przy czym trzeba uwzględniać konieczność tego, żeby wybrany sposób obciążenia wytwarzał na obszarze możliwego defektu koncentrację naprężeń (odkształceń). Opracowana metoda oceny ilościowej średnicy jądra punktowych połączeń zgrzewanych z użyciem mechanicznego obciążenia przebiega w przedstawiony dalej sposób.

Badana próbka zgrzewana, składa się z dwóch płyt metalowych o wymiarach 125 x $37 \mathrm{~mm}$, łączona jest za pomocą zgrzewania punktowego (rys. 1a).

Jeśli poprzeczna krawędź górnej płyty 1 jest sztywno zamocowana (strefa A), a obciążenie $P$ jest przyłożone do dolnej płyty 2 (strefa B), wtedy górna płyta ulega odkształceniu, co jest uwarunkowane obciążeniem i będzie się przenosić tylko przez jądro zgrzeiny 3 .

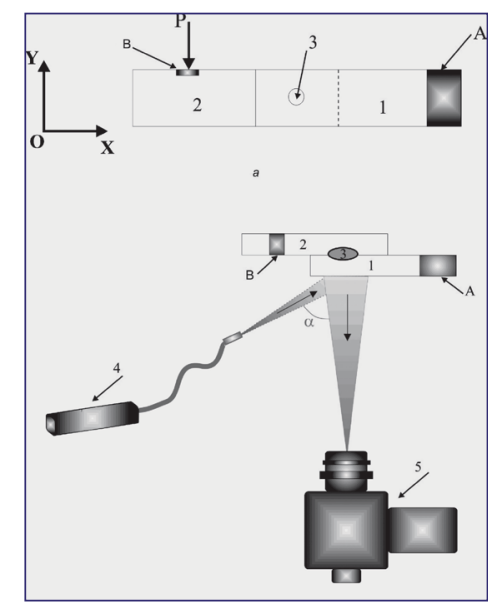

Rys. 1. Schemat eksperymentu, który wykonywano do numerycznej oceny średnicy jądra punktowego połączenia zgrzewanego (a-schemat obciążenia próbki; b - optyczny schemat eksperymentu): 1, 2 - części próbki zgrzewanej; 3 - punktowe połączenie zgrzewane; 4 - laser ze światłowodem; 5 - moduł szerograficzny; A - strefa umocnienia próbki; $\mathrm{B}$ - strefa podłączania obciążenia $P$

Fig. 1. Scheme of experiment which was made for quantitative evaluation of diameter of a weld spot nugget ( $a$ - scheme of specimen loading; b-optical scheme of experiment): 1, 2 - parts of welded specimen; 3- weld spot; 4 - laser with a light guide; 5 - electron shearography module; A - zone of specimen fixation; B - zone of loading applying $P$

Istotne jest, że w pobliżu punktowego połączenia zgrzewanego ma przewagę odkształcenie płyty w płaszczyźnie XOY. Zatem opracowano optyczny schemat eksperymentu, umożliwiający rejestrowanie odkształcenia płaszczyzny wzdłuż osi OY (rys. 1b). Promieniowanie lasera oświecało badany obszar próbki pod kątem $\lambda=60^{\circ}$ do powierzchni próbki, a kamera szerograficzna przemieszczała się wzdłuż badanej powierzchni. Należy wskazać, że wybrany schemat optyczny jest czuły na odkształcenia spoza płaszczyzn $\partial w / \partial y$. Zatem przy wykonaniu eksperymentów również uwzględniano odkształcenia $\partial w / \partial y$.

Otrzymawszy metodą elektronowej szerografii

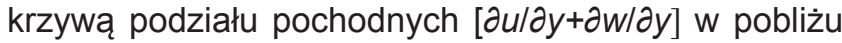
punktu zgrzewanego płyty, można wyznaczyć średnicę jądra. Wyniki eksperymentów pokazały, że średnica jądra zgrzeiny koreluje z odległościami między dwoma ekstremami krzywej podziału pochodnych od składowych $u$ i $w$ wektora przemieszczeń wzdłuż wybranego przecięcia podczas obciążenia punktowego połączenia zgrzewanego. Początkowe obciążenie $P$ dla wszystkich próbek wybrano takie, by kontrolowane przemieszczenie dolnego skraju płyty 2 wynosiło 30 mkm, a wielkość roboczego obciążenia dawała możliwość otrzymania ogólnego przemieszczenia 60 mkm.

Badania przeprowadzono na wzorcach wykonanych ze stali 14G2 o grubości 1,2 + 1,2 mm. Sprzęt do wyznaczenia średnicy jądra zgrzeiny z użyciem mechanicznego sposobu obciążenia przedstawiono na rysunku 2. Przy obciążeniu badanej próbki odległość między ekstremami krzywej przemian pochodnych płyty 1 zależy od rozmiaru jądra. 
Czym większa średnica jądra, tym większa odległość między ekstremami. Wyniki, otrzymane podczas kontroli próbki, przedstawiono na rysunku 3 (1 mm na obiekcie jest równy 50 pikselom na ekranie).

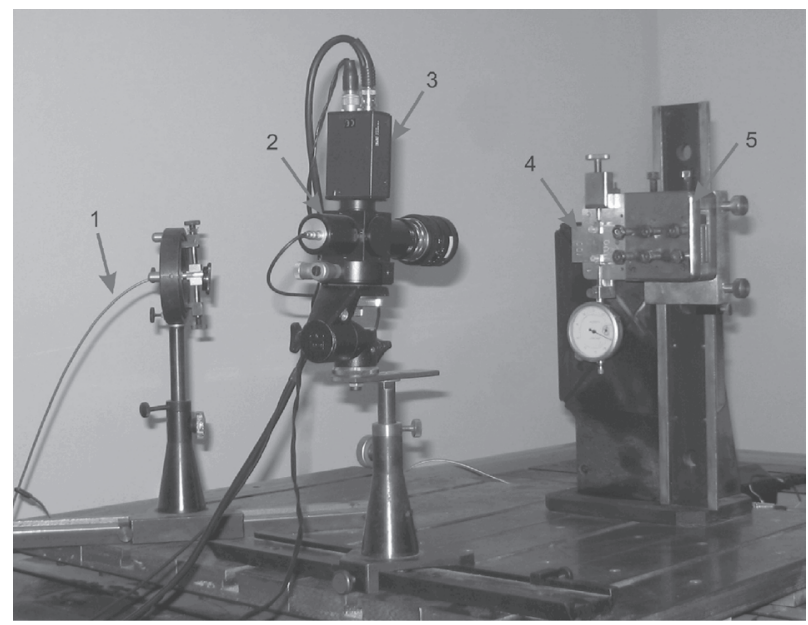

Rys. 2. Sprzęt do wyznaczenia średnicy jądra zgrzeiny z użyciem mechanicznego sposobu obciążenia: 1 - światłowód; 2 - moduł szerograficzny; 3 - CCD-kamera; 4 - badana próbka; 5 - urządzenie obciążające

Fig. 2. Equipment for determination of diameter of the weld spot nugget by means of mechanical method of loading: 1- light-guide; 2 - shearography module; 3 - CCD-camera; 4 - test specimen; 5 - loading equipment
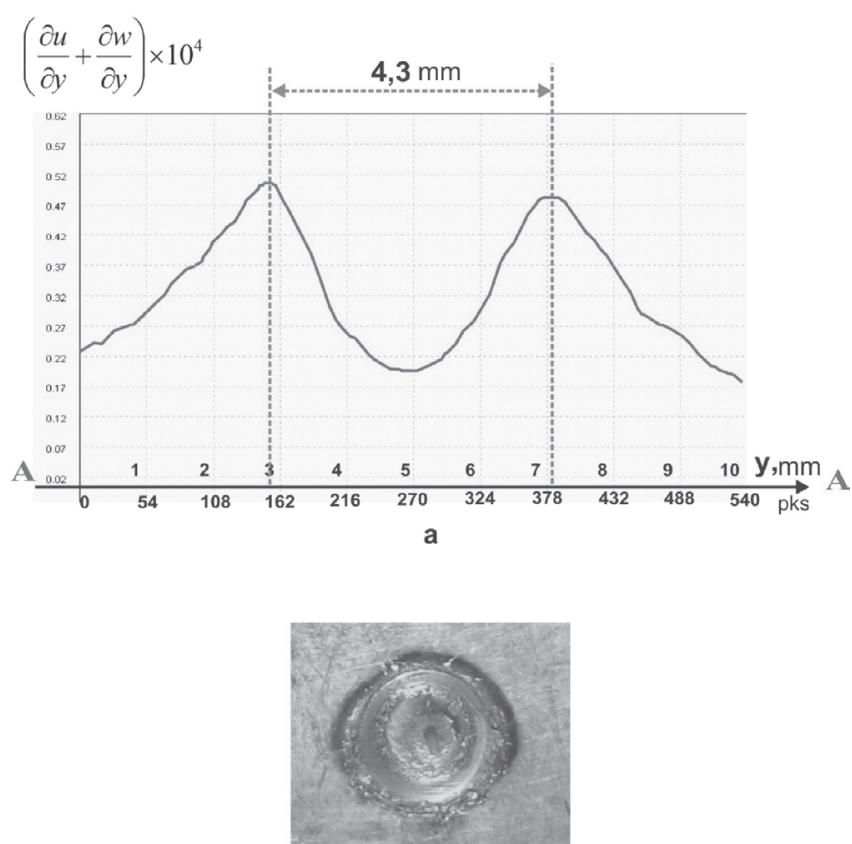

b

Rys. 3. Ocena średnicy jądra punktu zgrzewalnego badanej próbki ze stali 14G2 pod działaniem obciążenia mechanicznego $P$ : a) podział $\partial u / \partial y+\partial w / \partial y$ wzdłuż przekroju A-A, który przechodzi przez centrum zgrzeiny; b) fotografia zgrzeiny po znisz-czeniu (średnica jądra równa $4,39 \mathrm{~mm}$ )

Fig. 3. Evaluation of diameter of the wed spot nugget of the test specimen made of steel $14 \mathrm{G} 2$ under the action of mechanical loading $P$ $a-$ distribution of $\partial u / \partial y+\partial w / \partial y$ along A-A; crossing the center of weld spot; $b$ - photo of weld spot after destruction (diameter of the we'd spot nugget is equal to $4.39 \mathrm{~mm}$ )
Komputerowe opracowywanie szerogramu badanej próbki pozwoliło zbudować krzywą podziału zaznaczonych pochodnych $\partial u / \partial y+\partial w / \partial y$ wzdłuż wybranego przecięcia A-A (rys. 3a). Krzywa zmiany pochodnych wygląda jak krzywa z dwoma wyraźnymi ekstremami. Odległość między nimi jest tą wielkością, która charakteryzuje rozmiar zgrzeiny, czyli średnicę jądra.

W celu wyznaczenia realnych rozmiarów jąder badane próbki były zniszczone za pomocą zwijania jednej płyty względem drugiej. Na rysunku 3 przedstawiono fotografię zgrzeiny z wielkością średnicy jądra po naruszeniu spójności. W badanej próbce po jej zniszczeniu średnica jądra ma 4,39 mm, a według danych szerografii elektronowej $-4,3 \mathrm{~mm}$, czyli błąd wynosi $0,09 \mathrm{~mm}$.

\section{Wyniki badań}

Seria eksperymentów wyznaczenia średnicy jądra zgrzeiny daje możliwość otrzymania zgodności mierzonej odległości między ekstremami podziału pochodnych w otoczeniu punktów zgrzewanych pod działaniem obciążenia mechanicznego i realnych wielkości ich jąder dla próbek ze stali 14G2 o grubości $1,2+1,2 \mathrm{~mm}$ (rys. 4).

Wykonane badania udowodniły efektywność metody szerografii elektronowej do wyznaczenia średnicy jądra zgrzeiny z użyciem obciążenia mechanicznego węzłów i elementów konstrukcji. Analiza otrzymanych wyników pokazała, że wskutek odkształcenia połączenia punktowego na krzywej podziału pochodnych od składowych wektora przemieszczeń wzdłuż badanego przekroju, w zależności od kierunku przesuwu, pojawiają się dwa ekstrema, odległość między którymi jest związana z wielkością średnicy jądra. Przy czym należy wskazać, że w praktyce stosowanie mechanicznego obciążenia ograniczono obiektywnymi trudnościami, które są powiązane z załączaniem koniecznych obciążeń w rzeczywistych konstrukcjach.

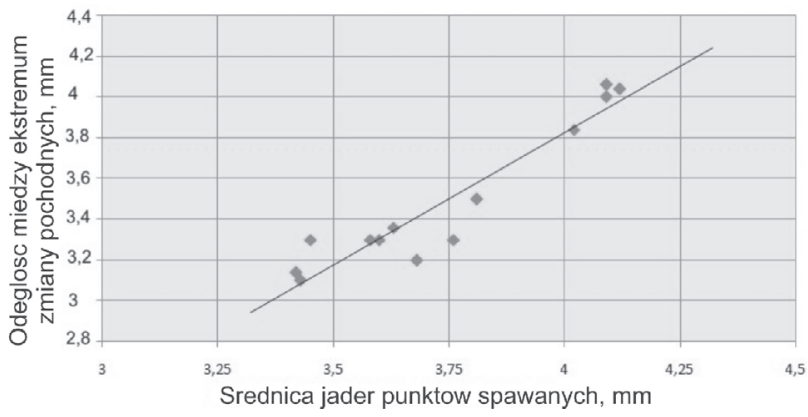

Rys. 4. Zgodność zmierzonej odległości między ekstremami podziału pochodnych $\partial u / \partial y+\partial w / \partial y$ w otoczeniu punktów zgrzewanych pod działaniem mechanicznego obciążenia i realnych wielkości ich jąder dla próbek ze stali $14 \mathrm{G} 2$ o grubości $(1,2+1,2 \mathrm{~mm})$

Fig. 4. Relation of measured distances between the extremum of derivatives $\partial u / \partial y+\partial w / \partial y$ in the vicinity of weld spots under the action of mechanical loading and real sizes of weld spot nuggets for specimens made from $14 \mathrm{G} 2$ steel of thickness $(1.2+1.2 \mathrm{~mm})$. 
Obciążenie termiczne jest bardziej uniwersalnym sposobem, który wywołuje w lokalnym obwodzie kontrolowanego obiektu regulowaną wielkość odkształcenia. Przy stosowaniu szerografii elektronowej opracowano metodykę wyznaczenia średnicy jądra zgrzeiny, która jest oparta na użyciu właściwości odkształcenia powierzchni w otoczeniu wielu punktów i uwarunkowana termicznym obciążeniem. Przy wykonaniu eksperymentalnych badań punktowych połączeń zgrzewanych stosowano ich termiczne obciążenie i rejestrację metodą szerografii elektronowej odkształcenia wzdłuż przekroju przez środek punktu zgrzewanego.

Do oceny efektywności metodyki wyznaczenia średnicy jądra zgrzeiny i wpływu wielkości średnicy, grubości zgrzewanych płyty, parametrów obciążenia termicznego i schematu optycznego na podział pochodnych od przemieszczeń wzdłuż wybranego przekroju w centrum zgrzeiny, wykorzystano modelowanie matematyczne metodą elementów skończonych.

Według wyników przeprowadzonych badań określono, że optymalny jest optyczny schemat z kątem do $10^{\circ}$ między kierunkiem oświetlenia i kierunkiem obserwacji, który zbiega się z prostopadłą do płaszczyzny powierzchni kontrolowanego elementu (rys. 1b). Najwięcej informacji o parametrach jądra punktu zgrzewalnego przy obciążeniu cieplnym dostarczają pochodne $\partial w / \partial x$ albo $\partial w / \partial y$ od przemieszczeń normalnych do powierzchni badanego obiektu.

$\mathrm{Na}$ podstawie modelowania matematycznego metodą elementów skończonych zniekształconego stanu powierzchni płyty w pobliżu punktowego połączenia zgrzewanego pod działaniem obciążenia termicznego określono wpływ wielkości średnicy jądra zgrzewanego punktu na krzywą podziału pochodnej $\partial w / \partial x$ albo $\partial w / \partial y$. Ustalono, że jak i w poprzednim przypadku obciążenia mechanicznego na krzywej podziału pochodnej obserwuje się dwa ekstrema, odległość pomiędzy którymi odpowiada średnicy jądra.

Metodyka wyznaczenia średnicy jądra zgrzeiny z użyciem obciążenia termicznego i szerografii elektronowej ma następującą kolejność działań:

- oświetlenie badanego obszaru połączenia zgrzewanego promieniowaniem lasera i zapis do pamięci komputera spekl-struktury, która odpowiada początkowemu stanowi powierzchni;

- obciążenie połączenia zgrzewanego za pomocą równomiernego albo lokalnego grzania;

- zapis do pamięci komputera spekl-struktury, która odpowiada obciążonemu stanowi powierzchni połączenia zgrzewanego;

- otrzymanie i komputerowe opracowywanie szerogramu, który implikuje informację o podziale pochodnej $\partial w / \partial x$ albo $\partial w / \partial y$ wzdłuż wybranego przekroju pod wpływem obciążenia termicznego połączenia zgrzewanego;

- wyznaczenie wielkości średnicy jądra punktu zgrzewalnego według otrzymanych danych eksperymentalnych.

Wykonane badania pokazały, że przy wyznaczeniu średnicy jądra zgrzeiny z dwustronnym dostępem do powierzchni połączenia zgrzewanego należy docelowo stosować przy termicznym obciążaniu równomierne grzanie połączenia zgrzewanego ze strony płyty dolnej.

Podczas prowadzenia eksperymentów grzanie realizowano elektryczną lampą o dużej mocy, która przemieszczała się na manipulatorze mechanicznym. Naprzeciw lampy przemieszczał się moduł szerograficzny z laserem, systemem oświetlenia i badana próbka testowa w taki sposób, żeby punkt zgrzewany znajdował się na osi optycznej interferometru szerograficznego (rys. 5).

Podczas prowadzenia eksperymentów wyznaczenia rozmiaru jądra punktu zgrzewanego przy równomiernym grzaniu lampą zmieniały się takie parametry termicznego obciążenia, jak trwałość grzania i natężenie źródła cieplnego.

Serię eksperymentów wykonano na próbkach ze stali 08KP o grubości 1,0 + 1,0 mm i ze stali $14 \mathrm{G} 2$ o grubości 1,2 + 1,2 mm. Badane podczas eksperymentów połączenia zgrzewane były przygotowane z użyciem różnych parametrów zgrzewania (zmieniało się natężenie prądu zgrzewania, czas zgrzewania i siła docisku elektrod zgrzewalniczych).

Jako przykład, na rysunku 6 przedstawiono wyniki, otrzymane przy wyznaczeniu średnicy jądra zgrzeiny w próbce ze stali $08 \mathrm{KP}$ z użyciem równomiernego grzania z dolnego boku próbki.

Na rysunku 6 przedstawiono również krzywą podziału pochodnej $\partial w / \partial y$ wzdłuż wybranego przekroju A-A, który odpowiada nagrzewaniu badanego obszaru powierzchni wzorca do ok. $5^{\circ} \mathrm{C}$ (1 $\mathrm{mm}$ na obiekcie odpowiada 45 pks na ekranie).

Wyznaczona metodą szerograficzną średnica punktu jądra zgrzewalnego była równa $5,33 \mathrm{~mm}$; średnica jądra, zmierzona po zniszczeniu punktu wynosiła $5,3 \mathrm{~mm}$, czyli błąd był równy $0,03 \mathrm{~mm}$.

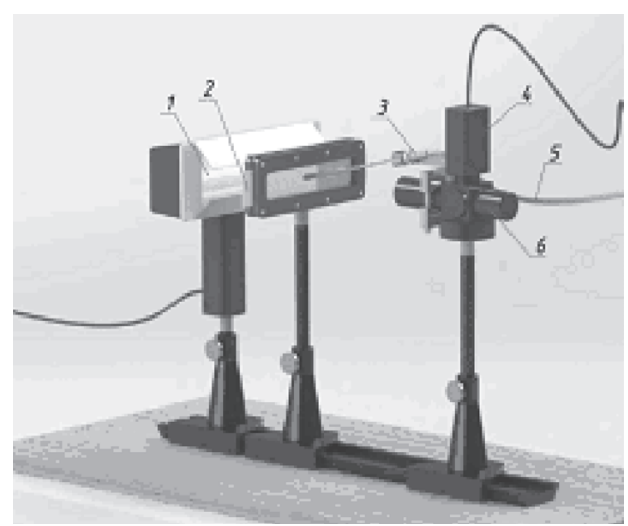

Rys. 5. Urządzenie eksperymentalne, w którym wykorzystywano termiczne obciążenie równomiernym grzaniem: 1 - lampka elektryczna; 2 - próbka z połączeniem zgrzewanym; 3 - nasadka kolimująca światłowodu, który doprowadza promieniowanie do oświetlenia i badanej działki; 4 - kamera wideo; 5 - światłowód do oświetlenia działki badanej; 6 - moduł szerograficzny

Fig. 5. Experimental equipment which is used at thermal loading by uniform heating: 1 - electric lamp; 2 - specimen with welded joint; 3 - light-guide collimator which transmits the light to test part; 4 - video camera; 5 - light-guide for illumination of test part; 6 - shearography module 

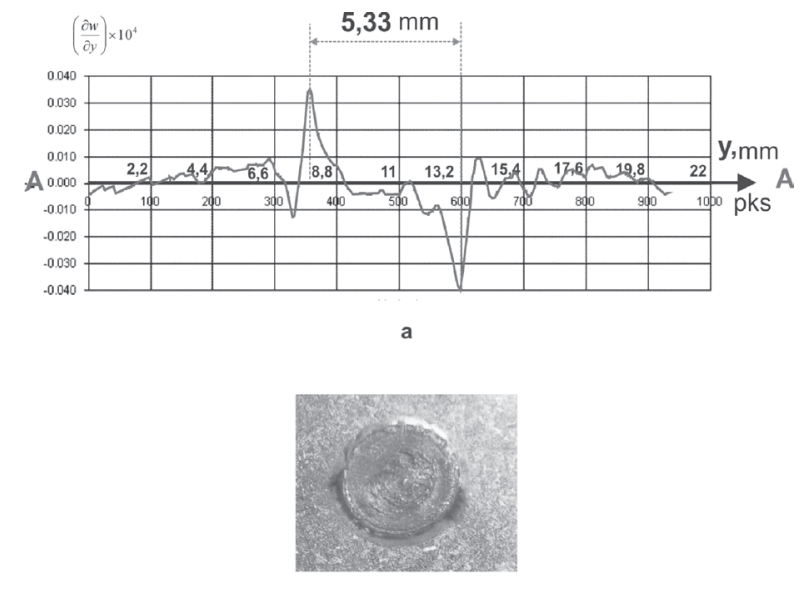

Rys. 6. Ocena średnicy jądra punktu zgrzewanego badanej próbki ze stali 08KP przy równomiernym nagrzewaniu lampą elektryczną z dolnej strony: a - podział pochodnej $\partial w / \partial y$ wzdłuż przekroju A-A, który przechodzi przez centrum punktu zgrzewanego; b - fotografia punktu zgrzewalnego po zniszczeniu (średnica jądra równa 5,3 mm) Fig. 6. Evaluation of diameter of the weld spot nugget of test specimen made from steel 08KP under the action of thermal loading by uniform heating on reverse side: $a-$ distribution of $\partial u / \partial y+\partial w / \partial y d e-$ rivative along $A-A$, crossing the center of weld spot; $b$ - photo of weld spot after destruction (diameter of the weld spot nugget is equal to $5.3 \mathrm{~mm}$ )

Przeprowadzono serię eksperymentów z użyciem termicznego obciążenia ze strony górnej badanych punktowych połączeń, przy wyznaczeniu średnicy jądra zgrzeiny.

Analiza wyników udowodniła, że równomierne grzanie ze strony górnej próbki nie daje możliwości wyznaczenia średnicy jądra punktu zgrzewanego. Wyjaśniono to tym, że przy równomiernym termicznym obciążeniu $z$ dolnej strony nagrzanie górnej płyty następuje przez jądro zgrzeiny i wizualizuje go, a przy grzaniu ze strony górnej ciepło równomiernie rozpowszechnia się po płycie i nie ujawnia jądra zgrzeiny.

Później lokalne grzanie punktu zgrzewanego ze strony górnej wykonano przy użyciu lasera o mocy średniej $200 \mathrm{~W}$.

Schemat eksperymentalnego urządzenia i wyznaczenia średnicy jądra zgrzeiny $z$ użyciem lokalnego grzania strefy połączenia zgrzewanego laserem $\mathrm{CO}_{2}$ przedstawiono na rysunku 7.

Szeromoduł i próbka badana przemieszczały się w ten sposób, żeby kąt między osią optyczną i kierunkiem obserwacji zbliżał się do $0^{0}$. Ze strony górnej płyty, pod kątem $45^{\circ}$, doprowadzano skolimowaną wiązkę od lasera o średnicy $7 \mathrm{~mm}$.

Podczas eksperymentów zmieniały się moc promieniowania lasera i trwałość lokalnego grzania połączenia zgrzewanego.

Wyniki otrzymane przy wyznaczeniu średnicy jądra zgrzeiny z użyciem lokalnego grzania z górnej strony próbki, wytworzonej ze stali $14 \mathrm{G} 2$, przedstawiono na rysunku 8 (1 $\mathrm{mm}$ na obiekcie odpowiada 30 pks na ekranie).

Punkt połączenia zgrzewanego był nagrzewany za pomocą lasera o mocy $100 \mathrm{~W}$ w ciągu ok. $5 \mathrm{~s}$ o ok. $5^{\circ} \mathrm{C}$.

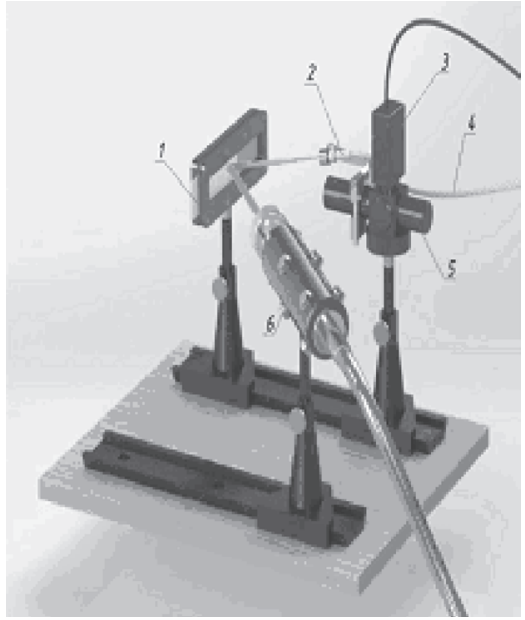

Rys. 7. Urządzenie eksperymentalne, w którym wykorzystywano obciążenie termiczne miejscowym (lokalnym) grzaniem: 1 - próbka z połączeniem zgrzewanym lampa elektryczna; 2 - nasadka kolimująca światłowodu, który doprowadza promieniowanie do oświetlenia badanej działki; 3 - kamera wideo; 4 - światłowód do oświetlenia działki badanej; 5 - moduł szerograficzny; 6 - kolimator lasera

Fig. 7. Experimental equipment which is used at thermal loading by uniform heating: 1 - specimen with welded joint; 2 - light-guide collimator which transmits the light to test part; 3 - video camera; 4 - light-guide for illumination of test part; 5 - shearography module; 6 - collimator of $\mathrm{CO}_{2}$ laser.

Średnica jądra, określona metodą szerograficzną, była równa $4 \mathrm{~mm}$; a zmierzona po zniszczeniu $4,2 \mathrm{~mm}$.

Wielkości średnic jąder zgrzeiny testowych próbek, określone metodą szerografii z użyciem termicznego obciążenia i zmierzone po zniszczeniu połączeń punktowych, przedstawiono w tablicy I. Błędy pomiaru średnic jąder zgrzein zmieniają się $\mathrm{w}$ zakresie $0,03 \div 0,4 \mathrm{~mm}$.

Konstrukcje z dużymi ilościami zgrzein punktowych występują w przemyśle samochodowym. Dlatego
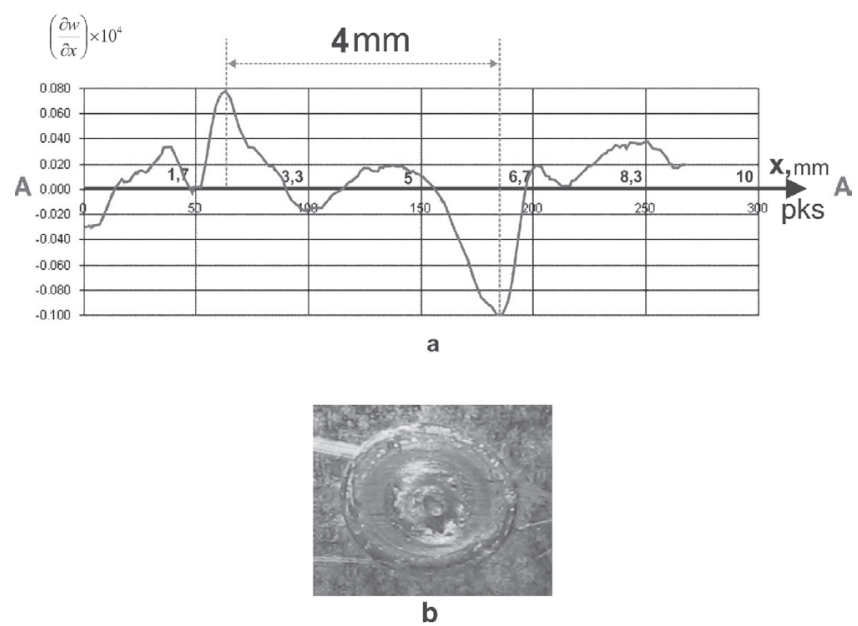

Rys. 8. Ocena średnicy jądra punktu zgrzewanego badanej próbki ze stali 14G2 przy równomiernym nagrzewaniu lampą elektryczną od

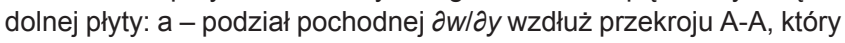
przechodzi przez centrum punktu zgrzewanego; $b$ - fotografia zgrzeiny po zniszczeniu (średnica jądra równa $4,2 \mathrm{~mm}$ )

Fig. 8. Evaluation of diameter of the weld spot nugget of test specimen made from steel $14 \mathrm{G} 2$ under the action of thermal loading by uniform heating on reverse side: $a-$ distribution of $\partial u / \partial y+\partial w / \partial y$ derivative along $\mathrm{A}-\mathrm{A}$, crossing the center of weld spot after destruction (diameter of the weld spot nugget is equal to $4.2 \mathrm{~mm}$ ). 
Tablica I. Wielkości średnic jąder zgrzein testowych próbek

Table I. Diameters sizes of the tested specimen weld spot nugget

\begin{tabular}{|c|c|c|c|c|}
\hline Próbka N & $\begin{array}{c}\text { Materiał } \\
\text { próbek }\end{array}$ & $\begin{array}{c}\text { Grubość płyt } \\
\text { zgrzewanych, mm }\end{array}$ & $\begin{array}{c}\text { Średnica, określona metodą } \\
\text { szerografii, mm }\end{array}$ & $\begin{array}{c}\text { Średnica, zmierzone } \\
\text { po zniszczeniu, mm }\end{array}$ \\
\hline 1 & $08 \mathrm{KP}$ & $1,0+1,0$ & 5,33 & 3,3 \\
\hline 2 & $14 \mathrm{G} 2$ & $1,2+1,2$ & 4,00 & 4,2 \\
\hline 3 & $14 \mathrm{G} 2$ & $1,2+1,2$ & 3,10 & 2,8 \\
\hline 4 & $14 \mathrm{G} 2$ & $1,2+1,2$ & 4,60 & 4,8 \\
\hline 5 & $08 \mathrm{KP}$ & $1,2+1,2$ & 3,20 & 3,1 \\
\hline 6 & $08 \mathrm{KP}$ & $1,2+1,2$ & 4,50 & 4,8 \\
\hline 7 & $08 \mathrm{KP}$ & $1,2+1,2$ & 2,50 & 2,9 \\
\hline 8 & $08 \mathrm{KP}$ & $1,2+1,2$ & 4,50 & 4,7 \\
\hline 9 & $08 \mathrm{KP}$ & $1,2+1,2$ & 4,00 & 4 \\
\hline
\end{tabular}

w pracy były wykonane eksperymenty zastosowania metody szerografii do wyznaczenia nieniszczącego średnicy jądra punktu zgrzewalnego. Dla przykładu przedstawiono próbkę testową, która przedstawia dwie płyty o wymiarach 150x130 mm i grubości 1,2 mm ze stali 08KP, które łączono ze sobą zgrzewaniem kontaktowym pięcioma punktami (rys. 9).

$\mathrm{Na}$ rysunku 10 przedstawiono podział pochodnej

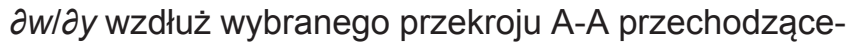
go przez centrum punktu, która odpowiada termicznemu obciążeniu badanego punktu za pomocą lokalnego

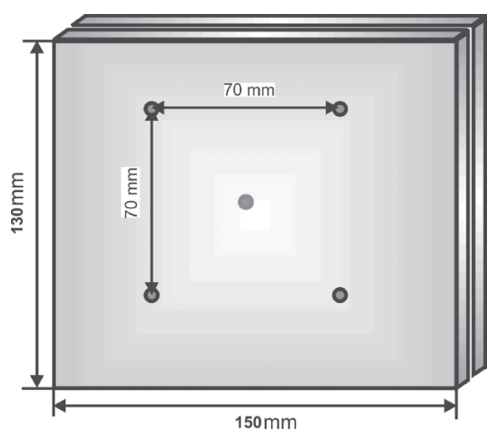

Rys. 9. Schemat próbki testowej do nieniszczącego wyznaczenia średnicy jądra zgrzeiny, znajdującej się wśród innych połączeń punktowych Fig. 9. Scheme of test specimen for non-destructive evaluation of diameter of weld spot nugget which is located in the clusters of other spot welds

\section{Wnioski}

Eksperymenty potwierdziły efektywność użycia metody szerografii elektronowej do nieniszczącego wyznaczenia rozmiaru średnicy jądra zgrzeiny. Mechaniczne obciążenie może być wykorzystane na próbkach testowych w warunkach laboratoryjnych. Bardziej efektywne do stosowania na obiektach naturalnych jest obciążenie termiczne. Optymalne do nieniszczącego wyznaczenia średnicy jądra zgrzeiny przy obustronnym dostępie jest użycie równomiernego grzania dolnej strony elementu, a przy jednostronnym dostępie - lokalnego grzania zgrzeiny z górnej strony.

Przy wykonaniu eksperymentów błąd średnicy jądra

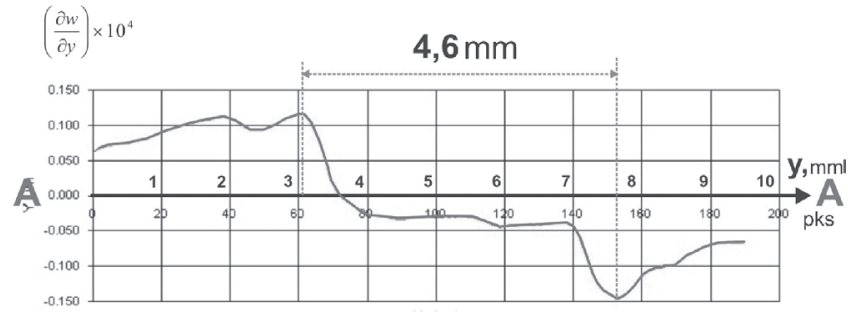

Rys. 10. Podział pochodnej $\partial w / \partial y$ wzdłuż wybranego przekroju A-A, przechodzi przez centrum zgrzeiny (który znajduje się w otoczeniu zgrzewanych połączeń punktowych), w przypadku lokalnego nagrzewania promieniowaniem laserem $z$ głównej strony

Fig. 10. Distribution of $\partial u / \partial y+\partial w / \partial y$ derivative along $A-A$, crossing the weld spot center (which is located in the clusters of other spot weIds), in case of local heating by laser emission on face side

grzania do ok. $5^{\circ} \mathrm{C}$ od górnej strony z użyciem promieniowania lasera o mocy $25 \mathrm{~W}$ z wiązką o średnicy $5 \mathrm{~mm}$ i czasem grzania $5 \mathrm{~s}$ (1 $\mathrm{mm}$ na obiekcie odpowiada 20 pks na ekranie).

Średnica jądra, określona metodą szerograficzną, jest równa 4,6 mm, a zmierzona po zniszczeniu 4,8 mm, czyli błąd wynosi 0,2 mm.

Przeprowadzone badania udowodniły, że ponieważ podział pochodnej $\partial w / \partial x$ albo $\partial w / \partial y$ wyznacza się w bezpośredniej bliskości zgrzeiny, to sąsiednie połączenia zgrzewane nie wpływaja na odkształcenie powierzchni w tej okolicy, jeśli odległość między takimi punktami wynosi więcej niż $20 \mathrm{~mm}$. zgrzeiny metodą szerografii elektronowej z użyciem termicznego obciążenia nie przekraczał $0,4 \mathrm{~mm}$.

Ustalono, że pod działaniem obciążenia termicznego odkształcenie zgrzeiny, znajdującej wśród innych, ma taki sam charakter, jaki dla pojedynczej, jeśli odległość między nimi jest większa niż $20 \mathrm{~mm}$.

Wyniki przeprowadzonych badań mogą być podstawą dla opracowania technologii bezstykowego wyznaczenia nieniszczącego średnic jąder zgrzein punktowych cienkościennych konstrukcji w warunkach przemysłowych. 


\section{Literatura}

[1] Technologia elektrycznego zgrzewania metali i stopów stopieniem,Pod red. B.Je. Patona - Moskwa: Mashynostrojenije, 1974.-768 s.

[2] Ocena jakości kontaktowego zgrzewania punktowego za pomocą sieci neuronowych, B.Je. Paton, H.B.Podoła, W.S.Gawrisz, W.W. Luklwicz, Zgrzewanie automatyczne, 1998, N 12, s. 3-10.

[3] Metody i technologia неразрушающего kontroli nieniszczącej jakości zgrzewania punktowego, S.W. Bobrow, Nowe technologie w diagnostyce przemysłowej i bezpieczeństwie, 2012, N 3, s. 56-67.

[4] Badanie i wprowadzenie technologii ND jakości zgrzewania punktowego karoserii samochodów LADA w SA "Awtowaz",Nowikow A.W., Khakimianow R.R., Grigorowicz W.W., Semerenko A.W. W świecie kontroli nieniszczącej, 2009, N 2, s.66-69.

[5] Stosowanie szerografii dla kontroli detali w przemyśle aerokosmicznym, Collern Jorg, Grysik Rene, Zibert Torsten, W świecie kontroli nieniszczącej, 2007, N 2, s. 28-31.

[6] Shearography: An optical measurement technique and applications,Y.Y.Hung, H.P.Ho, Materials Science and Engineering, 2005 , R49, s. 61-87.
[7] Metoda, technologia i aparatura kontroli nieniszczącej szerograficznej materiałów i elementów konstrukcji, L.M.Lobanow, W.A.Piwtorak I.W.Kijanec, Je.M.Olejnik, Diagnostyka techniczna i kontrola nieniszcząca, 2004, N 3, s.29-33.

[8] Kontrola operatywna jakości i wyznaczenie naprężeń szczątkowych w konstrukcjach zgrzewalniczych metodami szerografii elektronowej i spekl-interferometrii, L.M.Lobanow, W.A.Piwtorak, G.I.Tkaczuk, I.W.Kijanec, W.W.Sawicki, Zgrzewanie automatyczne, 2005, N 8, s.14-19.

[9] Kontrola nieniszcząca jakości konstrukcji, wytworzonych z materiałów metalowych i kompozycyjnych, metodą szerografii elektronowej, L.M.Lobanow, W.A.Piwtorak, P.D.Krotenko, I.W.Kijanec, 8-my Międzynarodowe sympozjum ukraińskich inżynierów-mechaników, 2325 maja 2007 r., Lwów. s.5-6.

[10] Diagnostyka elementów i węzłów konstrukcji z zastosowaniem metody szerografii elektronowej, L.M.Lobanow, W.A.Piwtorak, JeM.Sawicka, I.W.Kijanec, Diagnostyka techniczna i kontrola nieniszczaca, 2008, N 4, s.7-13.

[11] Measurement of nugget size of spot weld by digital shearography/ L.Yang, P.R.Samala, Optical Diagnostics, Proceedings of SPIE 2005, Vol.5880, s. 81-88.

\section{Dolnośląska Sekcja Spawalnicza SIMP Zakład Spawalnictwa Instytutu Technologii Maszyn i Automatyzacji i Wydział Mechaniczny Politechniki Wrocławskiej}

\section{zapraszają do udziału \\ w 4. Międzynarodowej Konferencji Naukowo - Technicznej pod hasłem „POSTĘP W TECHNOLOGIACH LUTOWANIA" WROCŁAW 2013}

Wrocław, 23-25 września 2013 (poniedziałek - środa) aula A1, bud. B-4 PWr, ul. tukasiewicza 5

Wszystkich zainteresowanych udziałem w Konferencji prosimy o kontakt z Zakładem Spawalnictwa ITMiA Politechniki Wrocławskiej

Prof. dr hab. inż. dr h.c. Władysław Włosiński - Przewodniczący Komitetu Naukowego IV Wydział Nauk Technicznych PAN Warszawa

Prof. dr hab. inż. Andrzej Ambroziak - Sekretarz Komitetu Naukowego tel. (071) 3202148, e-mail: andrzej.ambroziak@pwr.wroc.pl

Prof. dr hab. inż. Zbigniew Mirski - Przewodniczący Komitetu Organizacyjnego tel. (071) 3202142, e-mail: zbigniew.mirski@pwr.wroc.pl

Mgr inż. Anna Woźna - Sekretarz Komitetu Organizacyjnego tel. (071) 3202074, e-mail: anna.wozna@pwr.wroc.pl Dr inż. Tomasz Piwowarczyk - Sekretarz Komitetu Organizacyjnego tel. (071) 3204255, e-mail: tomasz.piwowarczyk@pwr.wroc.pl

Korespondencję prosimy kierować na adres:

Komitet Organizacyjny 4. Międzynarodowej Konferencji Naukowo - Technicznej "Postęp w technologiach lutowania"

Politechnika Wrocławska, Zakład Spawalnictwa ITMiA

Wybrzeże Wyspiańskiego 27 50-370 Wrocław 